\title{
Pelatihan Akuntansi dan Pelaporan Keuangan Guna Mendukung Kegiatan Kewirausahaan Mahasiswa Fakultas Ekonomi dan Bisnis Universitas Mataram
}

\author{
Hermanto*, Akram, Ni Ketut Surasni \\ Fakultas Ekonomi dan Bisnis, Universitas Mataram, Indonesia
}

Kata Kunci: tata cara pencatatan, pembuatan laporan keuangan, keterampilan berwirausaha

\begin{abstract}
Abstrak: Kegiatan Pelatihan akuntansi dan pelaporan keuangan bertujuan untuk memberikan penyuluhan kepada mahasiswa Fakultas Ekonomi dan Bisnis Universitas Mataram yang melakukan wirausaha tentang akuntansi dan pelaporan keuangan. Selain itu, pelatihan ini meningkatkan pengetahuan mahasiswa tentang tata cara pencatatan dan penyusunan laporan keuangan. Tujuan lain dari kegiatan ini juga yaitu memberikan pelatihan teknis kepada mahasiswa yang berwirausaha untuk membuat laporan keuangan. Kegiatan ini memberikan keterampilan kepada mahasiswa Fakultas Ekonomi dan Bisnis Universitas Mataram yang berwirausaha dalam menyusun perencanaan, pelaksanaan, dan pembuatan laporan keuangan , serta SDM yang mampu untuk membuat pencatatan pembukuan dan pengelolaan keuangan. Kegiatan pelatihan ditujukan pada mahasiswa Fakultas Ekonomi dan Bisnis. Pelaksanaan kegiatan dilakukan dengan pendekatan pemberian materi yang relevan dengan kebutuhan mahasiswa terkait kewirausahaan. Hasil kegiatan ini meningkatkan kualitas pelaporan keuangan kegiatan kewirausahaan mahasiswa Fakultas Ekonomi dan Bisnis Universitas Mataram.
\end{abstract}

Korespondensi:fjdbj@yahoo.co.id

\section{PENDAHULUAN}

Menghadapi Masyarakat Ekonomi Asean (MEA) dan Asean Free Trade Area (AFTA) saat ini, sebagian besar mahasiswa telah sadar betapa pentingnya wirausaha. Wirausaha di kalangan mahasiswa menjadi sangat penting mengingat angka pengangguran di Indonesia terus meningkat. Setelah lulus, mahasiswa harus bisa bertahan dengan kreativitas di tengah keterbatasan lapangan kerja. Untuk memasyarakatkan semangat kewirausahaan di tengah masyarakat, sebenarnya Pemerintah sudah mengeluarkan Instruksi Presiden Nomor 4 Tahun 1995. Tujuan dikeluarkannya Instruksi Presiden ini adalah untuk menumbuhkan semangat kepeloporan si kalangan generasi muda agar mampu menjadi wirausahawan. Terlebih dalam menghadapi era perdagangan bebas, semua aspek masyarakat dituntut untuk mampu mempersiapkan dan membuka lapangan kerja baru. Karena membuka dan memperluas lapangan kerja baru merupakan kebutuhan yang sangat mendesak.

Wirausaha untuk mahasiswa akan memberikan tujuan dan manfaat yang mulia. Tujuannya ada beberapa macam, yaitu sebagai berikut: Pertama, meningkatkan kecakapan dan keterampilan mahasiswa khususnya sense of business sehingga akan tercipta wirausahawirausaha muda potensial. Kedua, menumbuhkembangkan wirausaha-wirausaha baru yang berpendidikan tinggi. Ketiga, menciptakan unit bisnis baru berbasis IPTEKS; dan keempat, membangun jejaring bisnis antara pelaku bisnis wirausaha pemula dengan pengusaha (terutama UKM) yang sudah mapan. Sedangkan manfaat untuk mahasiswa sendiri adalah mempunyai kesempatan mengasah jiwa wirausaha, meningkatkan soft skill dengan terlibat 
langsung dalam dunia kerja, meningkatkan keberanian memulai usaha, mendapat dukungan modal dan pendampingan secara terpadu.

Mahasiswa Fakultas Ekonomi dan Bisnis Universitas Mataram telah mendapatkan materi perkuliahan terkait kewirausahaan. Hal ini memotivasi mahasiswa untuk menerapkan materi yang telah diperoleh di bangku perkuliahan pada kehidupan nyata. Biasanya mahasiswa menjalankan usaha-usaha kecil atau menengah bersama beberapa orang teman. Usaha-usaha yang dijalankan oleh mahasiswa biasanya lebih kreatif dibandingkan dengan usaha-usaha kecil menengah pada umumnya. Dalam menjalankan usahanya mahasiswa berfokus pada image produk yang dipasarkan untuk menarik minat konsumen.

Pengelolaan keuangan menjadi salah satu aspek penting selain image produk bagi kemajuan usaha. Pengelolaan keuangan dapat dilakukan melalui akuntansi. Akuntansi merupakan proses sistematis untuk menghasilkan informasi keuangan yang dapat digunakan untuk pengambilan keputusan bagi penggunanya. Sepanjang suatu usaha masih menggunakan uang sebagai alat tukarnya, akuntansi sangat dibutuhkan oleh mahasiswa sebagai pelaku usaha. Akuntansi akan memberikan beberapa manfaat bagi mahasiwa wirausaha, antara lain: (1) mahasiswa wirausaha dapat mengetahui kinerja keuangan usahanya, (2) mahasiswa wirausaha dapat mengetahui, memilah, dan membedakan harta usaha dan harta pribadi pemilik, (3) mahasiswa wirausaha dapat mengetahui posisi dana baik sumber maupun penggunaannya, (4) mahasiswa wirausaha dapat membuat anggaran yang tepat, (5) mahasiswa wirausaha dapat menghitung pajak, dan (6) mahasiswa wirausaha dapat mengetahui aliran uang tunai selama periode tertentu.

Melihat manfaat yang dihasilkan akuntansi, mahasiswa wirausaha seharusnya sadar bahwa akuntansi penting bagi usaha mereka. Penggunaan akuntansi dapat mendukung kemajuan usaha khususnya dalam hal keuangan. Peningkatan laba juga dapat direncanakan dengan menggunakan akuntansi. Dengan tingkat laba yang semakin meningkat, perkembangan usaha akan menjadi lebih baik sehingga kewirausahaan pada mahasiswa akan menjadi salah satu solusi bagi masalah perekonomian di Indonesia. Meskipun telah mendapatkan materi akuntansi dalam perkuliahan, masih banyak mahasiswa yang belum menggunakan akuntansi dalam menunjang kegiatan bisnisnya. Alasan mahasiswa tidak menggunakan akuntansi antara lain adalah akuntansi yang dipelajari pada saat perkuliahan berbeda dengan yang mereka hadapi di kehidupan nyata dimana saat perkuliahan yang dipelajari adalah akuntansi pada perusahaan-perusahaan besar.

Kurniawati et al (2012) menjelaskan bahwa penerapan akuntansi usaha kecil terutama usaha dagang masih sangat rendah karena kendala faktor pendidikan yang rendah termasuk dalam pengetahuan akuntansi dan kurangnya kesadaran akan pentingnya akuntansi. Sedangkan penelitian yang dilakukan oleh Wafirotin (2016) menyebutkan lebih dari 50\% UMKM mengalami kesulitan di sektor permodalan. Tidak adanya akuntansi dan pelaporan keuangan dalam pelaksanaan usaha dapat menyebabkan mahasiswa menjadi tidak tahu nilai untung dan rugi yang diperoleh dari usaha. Selain itu, aset usaha dan harta pribadi bisa bercampur karena tidak adanya pencatatan ataupun pemisahan di antara keduanya.

Berdasarkan permasalahan tersebut, perlu diadakan kegiatan pelatihan bagi mahasiswa yang berwirausaha terkait akuntansi dan pelaporan keuangan. Program pelatihan yang ditawarkan berupa pelatihan akuntansi sederhana bagi usaha yang dijalankan oleh mahasiswa. Akuntansi yang diajarkan adalah akuntansi sederhana yang disesuaikan dengan 
keadaan usaha mahasiswa namun tidak meyimpang dari standar dan peraturan yang ada. Pelatihan ini ditujukan bagi mahasiswa Fakultas Ekonomi dan Bisnis Universitas Mataram yang berwirausaha. Adanya pelatihan ini diharapkan mahasiswa wirausaha dapat mengetahui perkembangan usaha dan dapat memanfaatkan akuntansi dan pelaporan keuangan guna mendukung kemajuan usaha mereka.

\section{METODE KEGIATAN}

Mahasiswa yang melakukan kewirausahaan di Fakultas Ekonomi dan Bisnis Universitas Mataram masih memiliki pemahaman yang relatif sedikit terkait. Sementara dalam kewirausahaan tersebut dibutuhkan pelaporan keuangan sehingga dapat mengelola keuangan dengan lebih baik. Oleh sebab itu upaya yang dilakukan untuk meningkatkan pemahaman tentang akuntansi dan pelaporan keuangan bagi mahasiswa menjadi penting untuk dilaksanakan guna meningkatkan kualitas SDM.

Beberapa pendekatan dilakukan untuk melaksanakan kegiatan pelatihan akuntansi dan pelaporan keuangan. Adapun pendekatan atau metode yang digunakan dalam kegiatan pelatihan akuntansi dan pelaporan keuangan ini adalah sebagai berikut:

1. Mengidentifikasi kendala, kesulitan dan permasalah yang dihadapi mahasiswa;

2. Menyiapkan rancangan materi pendampingan yang aplikatif untuk langsung diterapkan oleh mahasiswa;

3. Mengidentifikasi, memilih dan mengumpulkan kendala-kendala yang dihadapi untuk dicarikan solusi atas permasalahan yang dihadapi;

4. Mempersiapkan waktu dan tempat serta jadwal pelaksanaan kegiatan pendampingan sehingga kegiatannya dapat berjalan dengan baik;

5. Melaksanakan kegiatan pelatihan akuntansi dan pelaporan keuangan dengan menghadirkan pemateri yang mampu memberikan pemahaman yang bisa langsung diaplikasikan;

6. Pendekatan yang dilakukan dalam kegiatan pendampingan ini dilakukan melalui penyampaian materi oleh tim pengabdian, serta pendampingan tentang akuntansi dan pelaporan keuangan dalam kegiatan kewirausahaan;

Secara lengkap tahapan kegiatan pelatihan dan edukasi disajikan pada Gambar 1. 


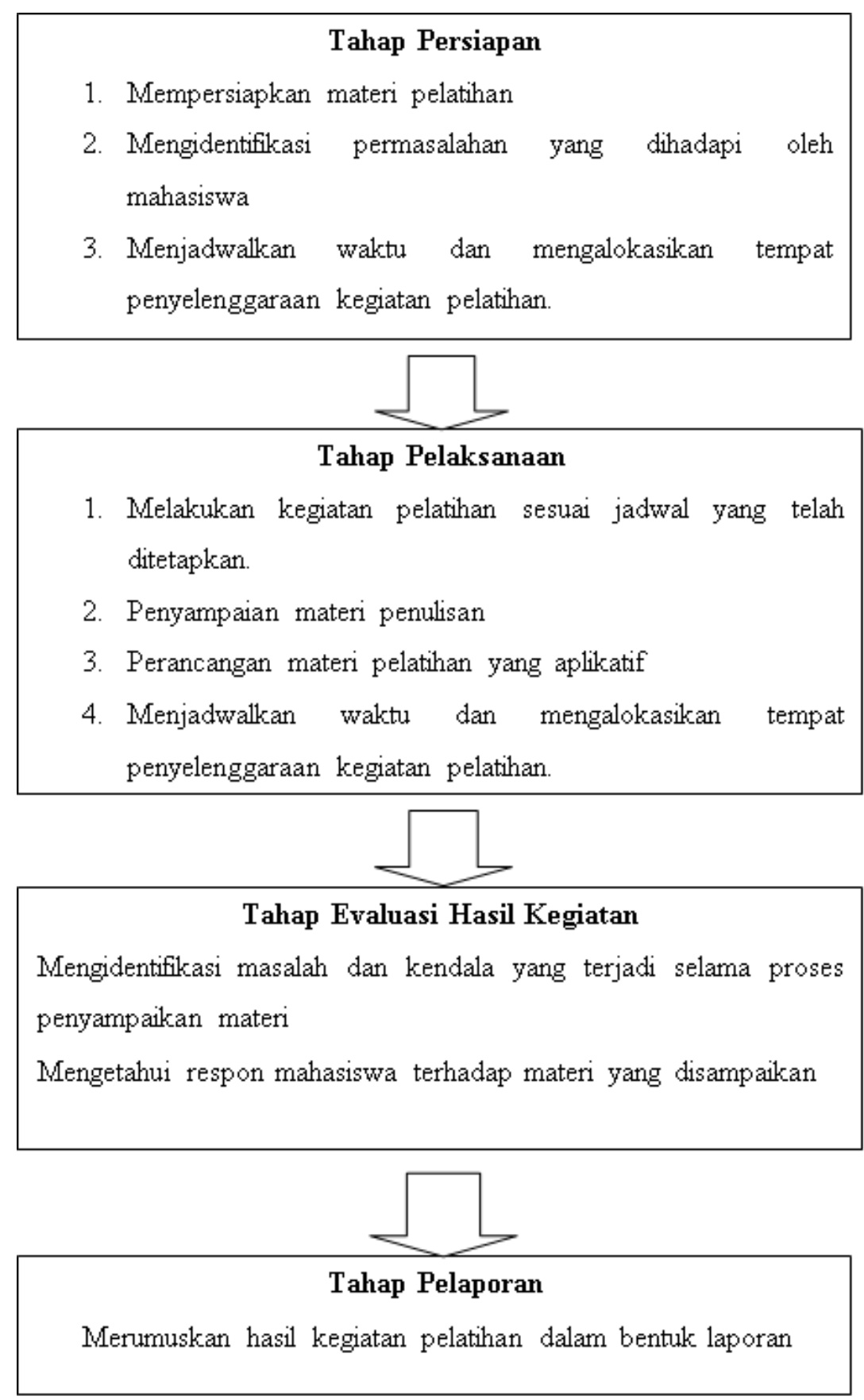

Gambar 1: Tahapan Kegiatan

\section{HASIL DAN PEMBAHASAN}

Kegiatan pengabdian dilakukan di Universitas Mataram pada hari Rabu Tanggal 28 Agustus 2019 pada pukul 19.00 Wita. Peserta pelatihan dihadiri oleh 30 orang mahasiswa fakultas ekonomi yang memiliki usaha. Sebelum kegiatan pelatihan ini dilakukan, tim pelaksana telah melakukan pemberitahuan informasi secara langsung kepada mahasiswa fakultas ekonomi yang memang telah melakukan usaha. Pemberitahuan informasi juga dilakukan melalui media sosial. Kemudian kegiatan pelatihan akuntansi dimulai dengan mempresentasikan materi mengenai akuntansi dan pelaporan keuangan guna mendukung 
kegiatan kewirausaan kepada peserta, yang dilanjutkan dengan sesi tanya jawab/diskusi antara pemateri dan peserta pelatihan.

Materi telah dipersiapkan dalam bentuk handout yang kemudian akan dibagikan pada peserta pelatihan. Hal ini bertujuan untuk mempermudah peserta dalam memahami pokok pembahasan yang akan diberikan oleh pemateri. Pemberian materi ini akan dilakukan dengan cara presentasi oleh pemateri dengan menampilkan slide powerpoint yang secara lengkap akan disajikan pada lampiran. Adapun materi yang diberikan secara garis besar adalah tentang “Akuntansi dan Pelaporan Keuangan", dan secara khusus materi yang disampaikan antara lain:

\section{Pengertian Kewirausahaan}

Kewirausahaan adalah perilaku dan kemampuan seseorang untuk menciptakan sesuatu yang bisa bermanfaat dan memiliki nilau jual. seorang yang memiliki semangat, sikap perilaku dan kemampuan kewirausahaan disebut dengan wirausaha. Seseorang yang berani mendirikan usaha adalah orang yang mengerahkan sumber daya. Upaya untuk memaksimalkan sumber daya tersebut adanya rancangan, ide, inovasi, proses, pengendalian dan tujuan. Peluang usaha sangat banyak tergantung bidang apa yang ingin di tekuni. Mendirikan usaha juga ada resiko yang perlu di pertimbangkan dengan baik. Kerena itu akan menjadi ancaman bagi mereka pengusaha. Seseorang yang memiliki sifat kewirausahaan adalah orang-orang yang berjiwa dagang. Memiliki kemampuan mengelolah uang dan memutar uang untuk memperbesar usahanya. Seorang wirausaha juga harus bersifat kreatif dan inovatif yang bisa di tuangkan dalam memenejemen usahanya.

Kewirausahaan adalah jiwa keberanian untuk memulai dari nol. Memulai adalah hal yang mudah tetapi bertahan dan berkembang lebih besar itulah yang sulit. Usaha pasti ada pasang surutnya sehingga seorang wirausaha di tuntut agar bisa menyelesaikan setiap permasalahan yang ada. Usaha adalah kebebasan, banyak orang yang berbondong-bondong mendirikan usaha untuk memperbaiki perekonomian mereka. memiliki udah tidak perlu berpendidikan tinggi hanya perlu berlajar teori dan mempraktekannya. Beberapa pengertian kewirausahaan yaitu sebagai berikut.

\section{Menurut Suparman Sumahamijaya}

Kewirausahaan adalah sebuah kemampuan dalam berpikir secara kreatif dan melakukan inovasi. Pikiran kreatif dan inovasi ini merupakan dasar dan juga sumber penggerak sehingga dapat digunakan sebagai tumpuan dalam menghadapi tantangan di depan.

\section{Menurut S Wijandi}

Kewirausahaan merupakan sebuah sifat. Sifat berani dalam mengambil resiko.

Adapun tujuan berwirausaha yang harus di tanamkan dalam diri pengusaha adalah sebagai berikut:

- Niat dan tekat yang bulat. Membangun bisnis pada awal mula adalah niat mendirikan usaha dan berjanji akan menjalankan dengan sebaik mungkin.

- Ikut dalam seminar kewirausahaan untuk menambah ilmu dalam bisang usaha.

- Ikut serta pelatihan kemampuan wirausaha guna meningkatkan kesejahteraaan masyarakat.

- Menumbuhkan dan mengembangkan kesadaran kewirausahaan yang kokoh.

- Berbagi ilmu dan informasi apapun yang berkaitan dengan kewirausahaan. 
- Ide-ide dan inovasi untuk meningkatkan usaha.

Untuk menjadi seorang wirausahawan, maka ada proses yang perlu anda ikuti. Mendapatkan ide kreatif merupakan proses pertama dalam berjalannya kewirausahaan. Untuk mendapatkan ide kreatif ini, maka berikut ini adalah proses yang perlu dilakukan.

1. Mencari Masalah dan Peluang

2. Tentukan Besar Kecilnya Peluang

3. Perencanaan

4. Mulai Mencari Sumber Daya

5. Mulai Usaha

Kewirausahaan juga memiliki ciri-ciri yang menyebabkannya keberhasilan dalam melakukan usaha, antara lain:

1. Keyakinan

2. Dekat dengan kompetitor

3. Orientasi masa depan

Selain memiliki sifat dan juga ciri di atas, ada juga beberapa faktor yang mempengaruhi sukses tidaknya sebuah kegiatan kewirausahaan yaitu:

- Faktor managerial

- Faktor sumber daya manusia

- Faktor pengalaman

- Perencanaan yang kurang

- Pengendalian modal yang kurang

\section{Pengertian Akuntansi}

Akuntansi merupakan sebuah metode pencatatan keuangan bisnis yang sistematis dan komprehensif. Sebagai sebuah disiplin ilmu, akuntansi memiliki kaidah yang baku dalam mencatat dan menyajikan data keuangan. Kaidah akuntansi yang paling mendasar yang harus dipahami oleh seorang pembelajar akuntansi yaitu persamaan dasar akuntansi. Persamaan dasar akuntansi atau persamaan akuntansi adalah sebuah persamaan matematis yang menyatakan hubungan antara komponen-komponen dalam akuntansi yang disebut dengan akun misalnya aset (harta), liabilitas (kewajiban), ekuitas (modal). Jika dinyatakan secara matematis, persamaan neraca adalah sebagai berikut:

\section{Aset $=$ Liabilitas + Ekuitas}

Selain persamaan neraca, pada akuntansi dikenal persamaan lain yaitu persamaan laba/rugi. Jika dituliskan secara matematis, persamaan laba rugi sebagai berikut:

\section{Laba $/$ Rugi $=$ Pendapatan - Beban}

\section{Laporan Keuangan}

Laporan keuangan adalah informasi tentang keuangan sebuah perusahaan yang bisa dipakai untuk melihat bagaimana kinerja perusahaan tersebut didalam suatu periode tertentu. Dengan adanya laporan keuangan ini, maka pelaku bisnis bisa lebih real melihat kondisi keuangan perusahaan berdasarkan data-data aktual tentang kondisinya. Agar bisnis bisa berjalan lebih lancar, maka harus dilengkapo dengan sistem pelaporan keuangan yang baik dan tertata. Tanpa ada laporan keuangan, maka sudah pasti perusahaan akan kesulitan menganalisisi apa yang terjadi di perusahaan Anda. Jenis-Jenis Laporan Keuangan antara lain: 


\section{$\checkmark$ Laporan Laba Rugi}

Laporan laba rugi adalah salah satu laporan keuangan yang menunjukkan pendapatan, pengeluaran, dan laba atau kerugian yang dihasilkan perusahaan selama periode waktu tertentu dan termasuk hal penting yang penting Anda ketahui jika ingin belajar akuntansi dari dasar. Laporan laba rugi adalah laporan keuangan pertama yang biasanya dihasilkan selama siklus akuntansi. Karena laba atau rugi bersih harus dihitung dan dilaporkan kepada pemilik modal sebelum laporan keuangan lainnya dapat dilaksanakan. Laporan laba rugi dibuat untuk menghitung laba bersih perusahaan dengan mengurangi seluruh total pengeluaran dari total pendapatan tentunya sesuai pata yang ada pada jurnal umum. Tidak seperti neraca, laporan laba rugi menghitung laba atau rugi bersih selama rentang waktu tertentu, dan hal ini termasuk dalam prinsip dan konsep dasar akuntansi.

\section{$\checkmark$ Laporan Neraca}

Laporan Keuangan Neraca adalah laporan keuangan yang menyajikan akun-akun aktiva, modal dan kewajiban dalan satu periode tertentu. Umumnya, neraca terdiri dari dua bentuk yakni skontro (horizontal) dan stafel (vertikal). Nilai modal pada neraca adalah nilai yang tercatat di Laporan Perubahan Modal. Keseimbangan pada neraca bisa didapat karena pada laporan tersebut sudah terdiri dari pendapatan dan biaya yang tercatat di laporan laba rugi.

\section{$\checkmark$ Laporan Arus Kas}

Laporan cash flow atau disebut laporan arus kas adalah laporan keuangan yang isinya tentang penerimaan dan pengeluaran kas dalam sebuah perusahaan pada waktu periode tertentu. Dengan adanya laporan cash flow ini kita akan bisa mengetahui tentang keuangan dari perusahaan apakah sedang untung ataukah rugi. Untuk bisa membuat laporan cash flow membutuhkan semua catatan tentang penerimaan dan pengeluaran kas perusahaan dalam periode tertentu. Arus kas yang keluar adalah yang termasuk semua beban-beban yang harus dibayarkan oleh perusahaan. Di akhir laporan cash flow, manajemen bisa menilai posisi keuangan perusahaan, apakah ada keuntungan atau minus. Ada tiga elemen penting dalam cash flow, yaitu:

a. Arus kas dari kegiatan bisnis (operating activities)

Arus kas yang pertama ini adalah arus kas yang berasal dari kegiatan bisnis baik pemasukan atau pengeluaran. Contohnya: penerima dari konsumen, membayar gaji bulanan, bayar listrik, dan lain sebagainya.

b. Arus kas dari kegiatan investasi (investing activity)

Arus kas ini berasal dari kegiatan investasi perusahaan baik itu pemasukan atau pengeluaran. Kegiatan yang masuk ke dalam investasi ini adalah aktivitas penjualan dan pembelian dari aktiva perusahaan dan kegiatan yang ada hubungannya dengan piutang perusahaan. Contohnya: pembelian kendaraan baru.

c. Arus kas dari kegiatan pendanaan (financing activities)

Arus kas yang ketiga ini adalah arus kas yang asalnya dari pendanaan yang didapatkan oleh perusahaan. Contohnya: emisi saham, penjualan obligasi, dan lain sebagainya.

Setelah mendengarkan ceramah tentang akuntansi dan pelaporan keuangan kewirausahaan, maka bagian kedua dari kegiatan pengabdian adalah memberikan kesempatan kepada peserta untuk mengajukan pertanyaan dan mendiskusikan secara bersama dengan tim 
pelaksana serta melibatkan partisipasi aktif dari peserta pelatihan. Beberapa pertanyaan yang diajukan adalah sebagai berikut:

1. Bagaimana cara untuk memulai kembali usaha yang pernah gagal? Dan bagaimana cara untuk mengatasi masalah kebutuhan modal untuk memulai usaha?

2. Bagaimana cara mengembangkan usaha yang semakin merosot seiring dengan kemajuan teknologi?

3. Bagaimana cara mengatasi rasa pesimistis yang muncul di saat ingin memulai usaha karena besarnya persaingan usaha?

4. Apa yang harus dipertimbangkan dalam memilih lokasi usaha?

Dalam menanggapi pertanyaan dari peserta, tim pelaksana memberikan penjelasan terkait akuntansi dan pelaporan untuk kewirausahaan. Berikut adalah ringkasan jawaban atas pertanyaan yang diajukan oleh peserta:

1. Saat memulai usaha, tentu yang pertama harus dilakukan adalah menganalisis peluang usaha. Kegagalan usaha yang dialami sebelumnya pasti disebabkan oleh adanya kesalahan dalam analisis usaha seperti lokasi usaha atau produk yang ditawarkan tidak sesuai dengan selera konsumen. Adanya keinginan memulai kembali usaha meskipun pernah mengalami kgagalan menunjukkan adanya jiwa kewirausahaan. Hal tersebut harus dipertahankan dan diiringi dengan memaksimalkan kemampuan menganalisis peluang agar usaha baru berhasil. Hal lain yang harus diperhatikan saat memulai kembali usaha adalah manajemen dalam usaha. Usaha sebelumnya bisa saja cukup diminati namun memiliki manajeman yang buruk sehingga menimbulkan kegagalan.

Usaha tidak harus dimulai dalam skala besar. Usaha bisa dimulai secara kecil-kecilan menggunakan modal sendiri dan kemudian dikembangkan secara perlahan dengan laba yang diperoleh dari usaha. Apabila ingin menambah modal, bisa menggunakan modal pinjaman. Modal pinjaman harus disesuaikan dengan kemampuan untuk membayar angsuran dan bunga pinjaman, jangan melebihi kapasitas yang mampu ditanggung oleh usahawan.

2. Seiring dengan berkembangnya teknologi, beberapa usaha menjadi tidak layak. Potensi pasar usaha tersebut digusur oleh kemajuan teknologi. Ada usaha yang masih bisa dikembangkan dengan menambah inovasi namun ada juga usaha yang sudah tidak layak dijalankan di era kemajuan teknologi saat ini. Untuk itu, usahawan dapat beralih ke jenis usaha yang sesuai dengan keadaan saat ini dengan memperhatikan peluang - peluang usaha yang tersedia.

3. Saat memulai usaha ditengah persaingan usaha yang sangat ketat tentunya akan menimbulkan perasaan khawatir apakah usaha yang akan dirintis dapat bertahan dan berkembang. Namun, perasaan khawatir tersebut harus dihilangkan agar usaha dapat dijalankan. Untuk itu, usahawan dapat menganalisis resiko yang akan dihadapi saat menjalankan usaha sehingga bisa memprediksi tindakan - tindakan pencegahan. Usahawan harus memproyeksikan risk dan return dari usaha secara konservatif, jangan agresif, sesuaikan dengan kapasitas usahawan. Usahawan juga dapat meningkatkan marketing dan promosi untuk menghadapi persaingan usaha. Dengan demikian usaha yang dijalankan akan mampu bertahan dan berkembang secara perlahan. 
4. Lokasi usaha merupakan salah satu faktor penentu kesuksesan usaha. Lokasi usaha yang strategis akan sangat mempengaruhi penjualan produk atau jasa yang ditawarkan. Beberapa hal yang harus diperhatikan dalam memilih lokasi usaha yang strategis antara lain memilih tempat yang mudah terlihat dan mudah diakses oleh kendaraan. Selain itu, harus memperhitungkan peluang usaha di lokasi yang diinginkan. Untuk menentukan peluang usaha, usahawan harus menentukan target pasar terlebih dahulu. Lokasi usaha sebaiknya cukup dekat dan mudah dijangkau oleh konsumen. Selain peluang, juga harus diperhitungkan resiko yang mungkin muncul di lokasi tersebut.

Secara umum kegiatan ini berjalan dengan sangat baik. Adapun indikator untuk menilai keberhasilannya adalah tingkat kehadiran peserta pelatihan yang tinggi, semangat yang begitu besar untuk mengikuti kegiatan pengabdian, tanya jawab yang aktif dan interaksi dua arah yang berlangsung dengan baik selama proses diskusi. Diharapkan kegiatan Pelatihan Akuntansi dan Pelaporan Keuangan tetap dilakukan guna mendukung kewirausahaan mahasiswa fakultas ekonomi dan bisnis Universitas Mataram. Adapun hal-hal yang masih dirasa kurang baik dalam pelaksanaan pengabdian akan ditingkatkan pada kegiatan mendatang, seperti praktik langsung dalam pembuatan laporan keuangan untuk kewirausahaan.

\section{KESIMPULAN DAN SARAN}

Tujuan kegiatan Pelatihan Akuntansi dan Pelaporan Keuangan yaitu memberikan penyuluhan kepada mahasiswa Fakultas Ekonomi dan Bisnis Universitas Mataram tentang akuntansi dan pelaporan keuangan untuk mendukung kewirausahaan mahasiswa. Kegiatan ini melibatkan 30 peserta mahasiswa Fakultas Ekonomi dan Bisnis Universitas Mataram.

Pendekatan ceramah, tanya jawab dan diskui dengan melibatkan partisipasi aktif dengan peserta pelatihan, serta menelaah pelaporan keuangan untuk meningkatkan pengetahuan mahasiswa terkait tata cara pencatatan dan penyusunan laporan keuangan. Materi yang disampaikan kemudian didiskusikan dalam kegiatan antara lain: definisi kewirausahaan, akuntansi, serta jenis-jenis laporan keuangan.

Hasil kegiatan pelatihan akuntansi dan pelaporan keuangan diharapkan dapat membantu mahasiswa dalam meningkatkan kualitas SDM serta pendapatan. Adapun indikator keberhasilan yang digunakan dalam kegiatan yaitu tingkat kehadiran peserta yang sangat tinggi, semangat yang besar untuk mengikuti kegiatan pelatihan, tanya jawab yang aktif serta interaksi dua arah yang baik antara tim pelaksana dan peserta selama proses diskusi berlangsung. Oleh karena itu, kegiatan pelatihan diharapkan selalu dilakukan untuk membatu dalam memberikan pemahaman yang lebih baik kepada mahasiswa yang berwirausaha. Adapun hal-hal yang masih kurang baik dalam pelaksanaannya akan ditingkatkan pada kegiatan yang akan datang, seperti praktik penyusunan laporan keuangan.

\section{Ucapan Terima Kasih}

Tim pengabdian mengucapkan terima kasih kepada Lembaga Penelitian dan Pengabdian kepada Masyarakat (LPPM), Badan Pengkajian dan Pengembangan Ekonomi dan 
Bisnis (BP2EB), dan Fakultas Ekonomi dan Bisnis melalui sumber dana BLU (PNBP) Universitas Mataram yang telah memberi kesempatan dan bantuan kepada tim pengabdian untuk melakukan kegiatan ini.

\section{DAFTAR PUSTAKA}

Arsyad, Lincolin. 2008. Pengantar Perencanaan dan Pembangunan Ekonomi Daerah. BPFE: Yogyakarta.

Agustina, Tri Siwi. 2015. Kewirausahaan: Teori dan Penerapan pada Wirausaha dan UKM di di Indonesia. Jakarta: Mitra Wacana Media.

Budiarto. 2015. Pengembangan UMKM. Gajah Mada University Press: Yogyakarta.

Gitosudarmo, Indrianyo, 2000 - Manajemen Pemasaran, Yogyakarta : BPFE 